\title{
NOTE
}

\section{A Screening Test to Detect HGH-Antibodies in Pituitary Dwarfs Treated with HGH Preparation by the Radio- immunoassay with Double Antibody Technique}

\author{
YOSHIAKI OKADA ${ }^{1}$, TATSUO TAKAHASHI ${ }^{2}$ \\ AND YUICHI KUMAHARA ${ }^{1}$ \\ ${ }^{1}$ Department of Medicine and Geriatrics, Osaka University Medical \\ School, Fukushima-ku, Osaka 553, Japan and ${ }^{2}$ Yodogawa \\ Christian Hospital, 57-1 Higashiyodogawa-ku, \\ Osaka 533, Japan
}

\begin{abstract}
Synopsis
Sixty-four blood samples, obtained from 25 pituitary dwarfs treated with KABIHGH preparation, were checked for serum $\mathrm{HGH}$ concentration by a double antibody radioimmunoassay and for antibodies against $\mathrm{HGH}$ by the method of propylethyleneglycol separation. Antibodies to $\mathrm{HGH}$ were detected in the samples whose HGH concentration was falsely estimated to be more than $5 \mathrm{ng} / \mathrm{ml}$, but not in those whose $\mathrm{HGH}$ concentration was $5 \mathrm{ng} / \mathrm{ml}$ or less. The measurement of $\mathrm{HGH}$ concentration by a double antibody technique in the serum obtained from pituitary dwarfs 3-4 days after the last injection can be used to screen the presence of antibodies to $\mathrm{HGH}$ preparation used.
\end{abstract}

Since HGH treatment of pituitary dwarfs was introduced, antibody formation to $\mathrm{HGH}$ has been widely discussed (Parker et al., 1964; Roth et al., 1964; Quabbe et al., 1967; Tanner and Whitehouse, 1967; Illing et al., 1970; Underwood et al., 1974). The procedure to detect antibodies in patients treated with $\mathrm{HGH}$ was originally based on chromatoelectrophoresis (Roth et al., 1964). It is, however, troublesome to check for antibodies in all samples routinely by this technique. This paper deals with a method to presume the presence of antibodies by means of measuring the serum $\mathrm{HGH}$ level of treated patients using a commercially available kit of $\mathrm{HGH}$ radioimmunoassay based on a double antibody method, which is the most popular technique in Japan.

Received March 15, 1977.

\section{Patients and Methods}

Twenty-five euthyroidal pituitary dwarfs were treated with KABI-HGH for a period of 6 months to 3 years and blood samples were monthly obtained 3-4 days after the last injection of $\mathrm{HGH}$. The $\mathrm{HGH}$ preparation was intramuscularly administrated in doses ranging 0.25 to $0.5 \mathrm{IU} / \mathrm{kg}$ of body weight/week. The serum was stored at $-20^{\circ} \mathrm{C}$ until analyzed for antibodies to $\mathrm{HGH}$ and $\mathrm{HGH}$ concentration. The serum HGH level was assayed by a double antibody radioimmunoassay using Dainabot kit. HGH antibodies in the serum were checked by a single antibody technique using polyethylene-glycol (PEG). Serum samples $(0.1 \mathrm{~m} l)$ were incubated with $0.1 \mathrm{ml}$ of ${ }^{125} \mathrm{I}$ $\mathrm{HGH}$ (approximately $10,000 \mathrm{cpm}$ ) in a total incubation volume of $0.7 \mathrm{ml}$, added with $0.5 \mathrm{ml}$ of borate buffer $(0.5 \mathrm{M}, \mathrm{pH} 8.6)$ containing $2.5 \%$ BSA. The tubes were kept at $37^{\circ} \mathrm{C}$ for $24 \mathrm{hr}$. The samples were diluted routinely to $1: 10$, to $1: 100$ and $1: 1000$ when it was necessary. Separation of the bound from free ${ }^{125}$ I-HGH was accomplished by PEG 20000 . Forty gram of PEG was dissolved in $100 \mathrm{ml}$ of borate buffer $(0.5 \mathrm{M}, \mathrm{pH} 8.6)$ and mixed for one hr with magnetic stirrer. Five tenth $\mathrm{m} l$ of PEG solution 
was added to each incubation tube and the mixture was centrifuged at $3,000 \mathrm{rpm}$ for $20 \mathrm{~min}$. The supernatant was removed with an aspirator and radioactivity of the percipitate was counted.

When ${ }^{125} \mathrm{I}-\mathrm{HGH}$, antibody-free serum and excess antibody of our radioimmunoassay were incubated, 'bound ${ }^{125} \mathrm{I}-\mathrm{HGH}$ ' separated from 'free' by the PEG method was $70 \%$, while ${ }^{125}$ I-HGH non-specifically bound to PEG was $20 \%$. Therefore, the titration of $\mathrm{HGH}$ antibodies were defined as the highest serum dilution binding $45 \%$ of the ${ }^{125} \mathrm{I}-\mathrm{HGH}$. When 'bound' was more than $20 \%$ but less than $45 \%$, the presence of antibodies in the serum is strongly suspected, but the antibody concentrations in less than $1: 1$ titer were decided to be negative in our studies.

\section{Results}

As a preliminary experiment, immunological cross-reactivity was compared between Wilhelmi $\mathrm{HGH}$ of our radioimmunoassay and $\mathrm{KABI}-\mathrm{HGH}$ used for treatment. When ${ }^{125}$ I-HGH (Wilhelmi) was used as tracer, the inhibition of binding to $\mathrm{HGH}$ antibodies by KABI-HGH was $84 \%$ of that of Wilhelmi HGH. Two $\mathrm{mg}$ of $\mathrm{HGH}$ was given to 3 pituitary dwarfs 2 times at intervals of $48 \mathrm{hr}$. Serum $\mathrm{HGH}$ levels increased from less than $3.0 \mathrm{ng} / \mathrm{ml}$ to the maximum levels ranging from 15 to $32 \mathrm{ng} /$ $\mathrm{m} l$ at 3 to $6 \mathrm{hr}$ after the injection and decreased to the basal level at $48 \mathrm{hr}$ in all cases studied.

Basal HGH levels of 25 pittuitary dwarfs studied were less than $3.6 \mathrm{ng} / \mathrm{ml}$ before the treatment and no antibodies to $\mathrm{HGH}$ were detected. In a serial dilution experiment as shown in Fig. 1, antibodies were detected at 3 months of the treatment. The titer of $\mathrm{HGH}$ antibodies in case 2 was $1: 10$ at 3 months and developed to $1: 200$ at 6 months of the treatment.

Sixty-four samples obtained from 25 pituitary dwarfs during the treatment were assayed for the level of serum $\mathrm{HGH}$ and simultaneously for the $\mathrm{HGH}$ antibodies. $\mathrm{HGH}$ levels were less than $5 \mathrm{ng} / \mathrm{m} l$ in 47 samples and more than $5 \mathrm{ng} / \mathrm{ml}$ in the other 17 samples. Antibodies to $\mathrm{HGH}$ could be detected in the latter but not in the former. Fig. 2 shows the relation between the falsely estimated $\mathrm{HGH}$ levels and the titer of antibodies. Dilution curves of 5 samples with falsely high $\mathrm{HGH}$ values were not parallel to the standard curve of the radioimmunoassay.

\section{Discussion}

A marked cross-reaction between KABI$\mathrm{HGH}$ and Wilhelmi $\mathrm{HGH}$ made it possitele to measure the KABI-HGH levels in the blood of patients injected with KABI-HGH by our radioimmunoassay using Wilhelmi $\mathrm{HGH}$ as a standard. Since the increased $\mathrm{HGH}$ level after the injection of KABI$\mathrm{HGH}$ decreased to the initial levels in 2 days, blood samples to detect $\mathrm{HGH}$ antibodies were taken 3-4 days after the last injection.

It seems that antibodies produced in these patients react with ${ }^{125} \mathrm{I}-\mathrm{HGH}$ in vitro, but in the case of the double antibody technique this soluble complex does not react with the second antibody, anti-guinea pig gammaglobulin goat serum, and remains in the supernatant after centrifugation. Therefore, the bound $\%$ in a double antibody technique is decreased when serum samples contain antibodies to KABI-HGH, and then falsely high results are obtained. The same is with TSH when endogenous antibodies to TSH are present (Chaussain et al., 1972). Since HGH antibodies produced in the patients during the treatment seem to be bound to endogenous $\mathrm{HGH}$ in rivo and to $\mathrm{HGH}$ preparation in vitro (Illig, 1972), the measurement of serum HGH by a double antibody radioimmunoassay can be used as a screening test for the presence of its antibody in pituitary dwarfs treated with $\mathrm{HGH}$ preparations. If blood samples are taken 3-4 days after the last injection of $\mathrm{HGH}$ and the $\mathrm{HGH}$ levels are more than $5 \mathrm{ng} / \mathrm{ml}$, they must be checked 


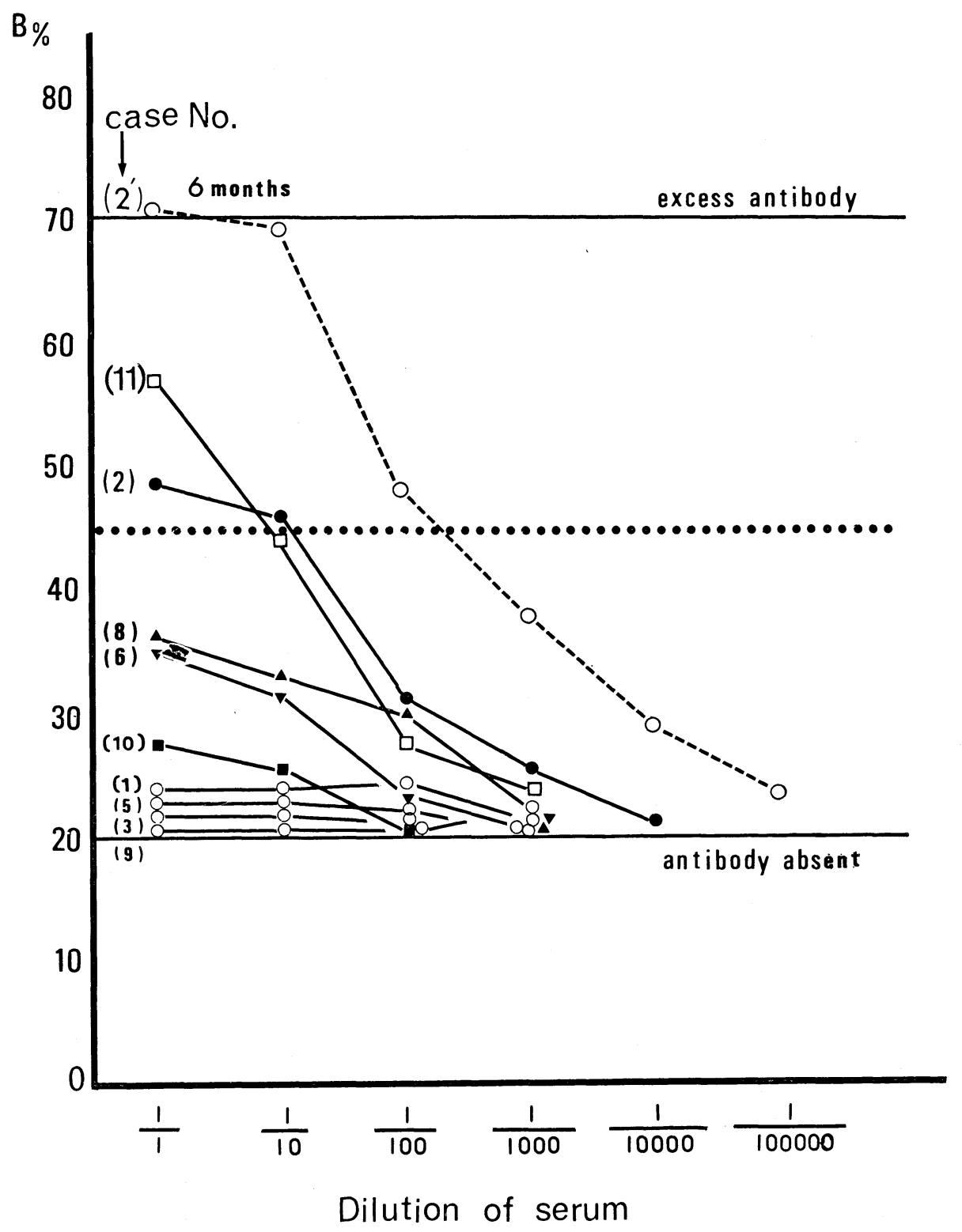

Fig. 1. Serial dilutional experiment to detect antibodies against HGH in 9 treated pituitary dwarfs. Blood samples were obtained at 3 months of treatment. Antibodies in a titer of $1: 10$ were detected in 2 of the 9 patients and the titer of Case 2 developed to $1: 200$ at 6 months of the treatment. 
for antibodies against HGH. This is a useful test for screening $\mathrm{HGH}$ antibodies in a laboratory where the routine radioimmunoassay for $\mathrm{HGH}$ measurement is a double antibody technique.

\section{Acknowledgements}

We are grateful to Miss M. Maekawa and Miss M. Hiramatsu for help in preparation of the manuscript. This work was supported by a Research Grant for Specific Diseases from the Ministry of Health and Welfare.

Ab. positive

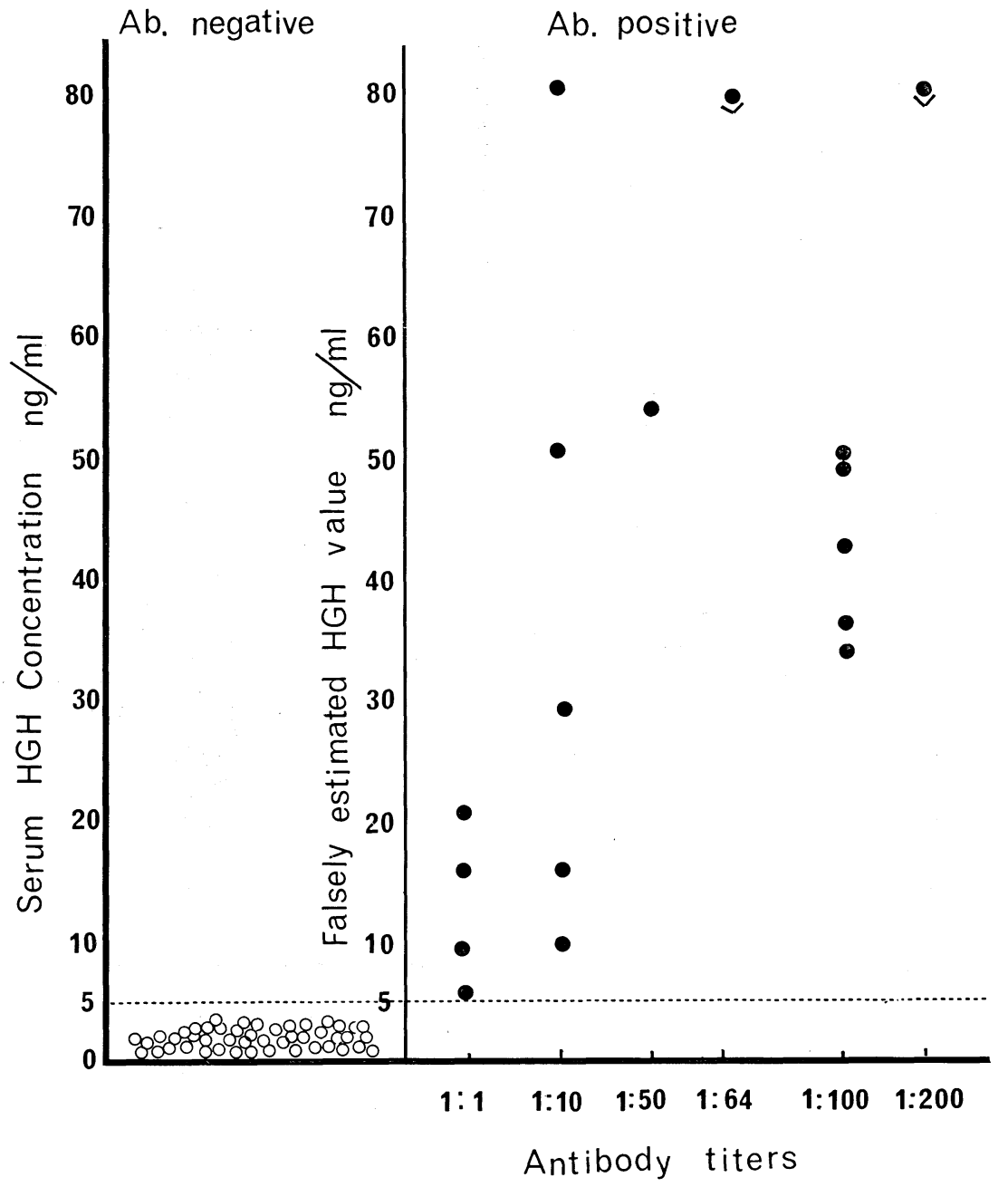

Fig. 2. Relation between titers of antibodies and falsely estimated HGH concentrations. Sixty-four samples obtained from 25 pituitary dwarfs on HGH preparation were checked for the presence of antibodies against $\mathrm{HGH}$ and simultaneously for the serum HGH levels by a double antibody technique. Antibodies to $\mathrm{HGH}$ were detected with the titers ranging from $1: 1$ to $1: 200$ in 17 samples whose HGH concentrations were falsely estimated to be more than $5 \mathrm{ng} / \mathrm{ml}$, but not in 47 samples whose $\mathrm{HGH}$ concentrations were less than $5 \mathrm{ng} / \mathrm{ml}$. 


\section{References}

Chaussain, J. L., E. Binet and J. C. Job (1972). Rev. Eur. Etud. Clin. Biol. XVII, 95.

Illig, R. (1970). J. Clin. Endocrinol. Metab. 31, 679. Illig, R. Human Growth Hormone (edited by A. Stuart Mason) William Heinemann Medical Books Limited. p. 144 (1972).
Parker, M. L., I. K. Mariz and W. H. Daughaday (1964). J. Clin. Endocrinol. Metab. 24, 997.

Quabbe, H. J., H. Helge and E. Werner (1067). Acta Endocrinol. Supple. 119, 17.

Roth, J., S. M. Glick, R. S. Yalow and S. A. Berson (1964). J. Clin. Invest. 43, 1056.

Tanner, J. M. and R. H. Whitehouse (1967). Brit. Med. J. II, 69.

Underwood, L., S. J. Voida and J. J. Van Wyk (1974). J. Clin. Endocrinol. Metab. 38, 288. 